\title{
Synthesis and Cytotoxicity of Novel Analogues of Podophyllotoxin
}

\author{
SamudyataC.Prabhuswamimath ${ }^{1}$, Sunil Kumar P. ${ }^{2}$, K. M. Lokanatha Rai \\ ${ }^{2}$ BharathiP.Salimath ${ }^{1}$, \\ ${ }^{1}$ Molecular Oncology Laboratory, Department of Studies in Biotechnology, University of Mysore, \\ Manasagangotri, Mysore, Karnataka 570 006, India. \\ ${ }^{2}$ Department of Studies in Chemistry, University of Mysore, Manasagangotri, Mysore 570 006, India.
}

\begin{abstract}
We have synthesized four novel derivatives of podophyllotoxin, the chalcone derivatives namely 2benzylidene-6,7-dimethoxy-4-phenyl-3,4-dihydro-2H-naphthalen-1-one (4a), 2-benzylidene-5,7-dichloro-6hydroxy-4-phenyl-3,4-dihydro-2H-naphthalen-1-one(4b), and the amino-thiazolyl derivatives namely7,8dimethoxy-5-phenyl-4,5-dihydro-naphtha[1,2-d] thiazol-2-yl amine (5a) and 2-amino-6,8-dichloro-5-phenyl4,5-dihydro-naphtho[1,2-d] thiazol-7-ol (5b). The aryl tetralin ring system in these compounds were attached to a fused aminothiazolyl ring or a chalcone ring. Synthesis of the tetralin ring in these podophyllotoxin derivatives was accomplished by the cyclization of the $\gamma$-hydroxyketones. These derivatives were evaluated for the induction of cytotoxicity in mouse mammary carcinoma cells in vitro. All the four compounds exhibited time dependent cytotoxicity at a concentration of $100 \mu \mathrm{M}$ when assessed by Trypan blue dye exclusion assay on Ehrlich Ascites Tumor (EAT) cells in vitro.
\end{abstract}

Keywords:Podophyllotoxin,Thiazolyl, Chalcone, Cytotoxicity, Ehrlich Ascites Tumor.

\section{Introduction}

Breast cancer is the second most prominent cause of death next to lung cancer in women [1].Chemotherapy with cytotoxic drugs is the preferred treatment modality used in the treatment of various cancers [2]. There are many FDA (Food and Drug Administration) approved chemotherapeutic drugs used clinically for breast cancer treatment namely Bevacizumab (Avastin), Paclitaxel, Gefitinib(Iressa), Lapatinib(Tykerb),Canertinib (CI-1033) targeting growth factor receptors [3][4].Studies on a new series of substituted-1, 3, 4-oxadiazole derivatives and imidazole derivatives in our laboratory have proved to be potent anti-breast cancer drugs with clinical applications [5][6].

Podophyllotoxin, having 1-phenyl tetrahydronaphthalene system belongs to the large family of natural products called lignans. Several of its analogs show wide variety of biological activities such as cathartic, antimitotic, anticancer, antimalarial, virucidal, fungicidal and are efficient antineoplastic drugs etc [7][8]. The mode of action of podophyllotoxin is by the interference with the microtubule assembly and thus proves to be an effective inhibitor of cell division[9]. Highly purified podophyllotoxin efficiently suppresses in-vitro and in-vivo immune responses. Researchers at Sandoz examined the possibility that podophyllumlignans might act as glycosides which paved the way for introduction of etoposideand teniposide as significant anticancer drugs[10][11][12]. Literature reveals that thiazole derivatives have a wide range of pharmaceutical activities like anti-viral, anti-bacterial, anti-cancer, anti-fungal and anti-inflammatory properties that are present in natural and synthetic products [13]. The 2-amino derivatives of thiazoles possess anti-cancer activity by the inhibition of kinases [14][15]. The chalcones are also an important class of compounds which are extensively investigated for a wide range of biological activity like anti-inflammatory [16], antitumor [17] and antibacterial [18] properties.Our interest in synthesizing the podophyllotoxin derivatives stems from the fact that the aminothiazolyl derivatives and chalcone derivatives of lignans can add to the therapeutic value of podophyllotoxin derivatives.Hence we designed the study to synthesize novel derivatives with greater therapeutic efficacy and evaluate theircytotoxicity and potencyin murine mammary carcinoma cells in an in vitro system.

\subsection{Chemistry}

\section{Results and discussion}

Synthesis of podophyllotoxin and its derivatives are widely reported in literature. Here in, we report a new method for the synthesis of the reported derivatives $(\mathbf{4 a}, \mathbf{4 b}, \mathbf{5 a}, \mathbf{5 b})$. The scheme of synthesis is shown in Scheme 1 .The central tetralin ring system in these derivatives was constructed by the cyclization of $\gamma$-hydroxy ketones (1) 
<smiles>O=C(CCC(O)c1ccccc1)c1cc(Br)c(Br)c(Br)c1</smiles>

1

a $\mathbf{R}_{1}=$ OMe, $\mathbf{R}_{2}=$ OMe, $\mathbf{R}_{3}=\mathbf{H}$

b $\quad \mathbf{R}_{1}=\mathrm{Cl}, \quad \mathbf{R}_{2}=\mathrm{OH}, \mathrm{R}_{3}=\mathrm{Cl}$<smiles>[R3]c1c([123I])cc2c(c1[R3])C(c1ccccc1)CCC2=O</smiles><smiles>Cc1ccc(O)cc1C</smiles><smiles>O=C1c2cc(Br)c(Br)c(Br)c2C(c2ccccc2)CC1Br</smiles>

3<smiles>O=Cc1ccccc1</smiles><smiles>O=C1/C(=C/c2ccccc2)CC(c2ccccc2)c2c1cc(Br)c(Br)c2Br</smiles>

4

Scheme 1: General Synthetic route.

Preparation of $\gamma$-hydroxy ketones was achieved using the procedure developed in our laboratory [19]. The tetralone (2) was prepared from $\gamma$-hydroxy ketones by the cyclization of $\gamma$-hydroxy ketones (1) using ptoluene sulphonic acid in nitromethane. The cyclization reaction was faster with the $\gamma$-hydroxy ketones having dimethoxy groups on the 3-phenyl ring (1a) compared to the 3-phenyl ring having chloro and hydroxyl groups (2a).

The chalcone derivatives, 2-benzylidene-6, 7-dimethoxy-4-phenyl-3, 4-dihydro-2H-naphthalen-1-one (4a) and 2-benzylidene-5, 7-dichloro-6-hydroxy-4-phenyl-3, 4-dihydro-2H-naphthalen-1-one (4b) were prepared by reaction of tetralones with benzaldehyde in basic medium at room temperature. The chalcone derivatives were isolated as solids in high yields.

Two more derivatives of podophyllotoxin, 7,8-dimethoxy-5-phenyl-4,5-dihydro-naphtha[1,2-d] thiazol-2-yl amine (5a) and 2-amino-6,8-dichloro-5-phenyl-4,5-dihydro-naphtho[1,2-d] thiazol-7-ol (5b) were prepared from tetralone (2). Bromination of tetralone (2) was performed using NBS in acetonitrile. 2-bromo derivative (3) was obtained as the exclusive product. The formation of dibromo derivative was reduced using lesser equivalents of NBS compared to the tetralone. The bromo derivatives ( $3 \mathrm{a}$ and $3 \mathrm{~b}$ ) were then treated with thiourea to prepare the aminothiazolyl derivatives (5a and $5 b$ ).

\subsection{Cell line:}

\section{Materials and methods}

EAT (Ehrlich Ascites Tumor) cells were cultured in 8-week-old Swiss albino mice, which is a preferred model for mouse mammary carcinoma. The EAT cells were isolated from the peritoneal cavity of the tumor bearing mice and $5 \times 10^{6}$ cells were transplanted into 8-week-old Swiss albino mice. The animal was sacrificed on the $12^{\text {th }}$ day and the cells along with the ascites were isolated, centrifuged and cells pelleted which was further diluted with sterile PBS in the ratio of 1:6.Swiss albino mice (6-8 weeks old) were obtained from the animal house, Department of Studies in Zoology, University of Mysore, Mysore,Karnataka, India. The animal experiments were approved by the institutional animal care and use committee. The culture medium used throughout these experiments was RPMI 1640, containing $10 \%$ fetal bovine serum (FBS), and $100 \mathrm{mg} / \mathrm{ml}$ penicillin streptomycin (Invitrogen).Ehrlich Ascites Tumor cells/mouse mammary carcinoma cells are being maintained in our laboratory by in vivo transplantation as an ascites tumor model. Other chemicals and reagents used were of analytical grade.

\subsection{Test compound preparation:}

All the test compounds were dissolved in Dimethyl Sulfoxide (DMSO) (0.1\%) solvent and filter sterilized using a $0.22 \mu \mathrm{m}$ syringe filter for use in experiments. In control samples, equimolar concentration of DMSO was added as vehicle to rule out its cytotoxic effect.

\subsection{Trypan Blue Dye Exclusion assay to assess preliminary cytotoxicity}

About $5 \times 10^{6}$ EAT cells were seeded in each of the 6 well culture plates with $2 \mathrm{ml}$ complete RPMI 1640 medium. After $16 \mathrm{~h}$, the media was freshly replaced with complete medium containing $100 \mu \mathrm{M}$ of the derivatives 
of podophyllotoxin and incubated for different intervals of time namely $45 \mathrm{~min}, 1.5 \mathrm{~h}, 3 \mathrm{~h}$ and 6 hat $37^{\circ} \mathrm{C}$ with $5 \%$ $\mathrm{CO}_{2}$ in a humidified incubator. The semi adherent cell suspension was harvested by centrifugationat $2500 \mathrm{x} \mathrm{g}$ for $5 \mathrm{~min}$ and washed with sterile PBS. The cell pellet was then re-suspended in sterile PBS. About $10 \mu \mathrm{L}$ of the cell suspension was stained with $980 \mu \mathrm{L}$ of sterile PBS and $10 \mu \mathrm{L}$ of $1 \mathrm{X}$ trypan blue dye. From this about $10 \mu \mathrm{L}$ of the suspension was placed on a haemocytometer and the viable cells were counted at each time interval. The percentage of viable cells was normalized to untreated cells and agraph of percentage of cell viability v/s time was plotted using GraphPad Prism 7.0.

\subsection{Statistics}

All experiments were performed in triplicates. Wherever appropriate, the data are expressed as the mean \pm SEM and means were compared using one-way analysis of variance. Statistical significance of differences between controls, compound treated cells was determined by Dunnet's test. For all tests, $\mathrm{P}<0.05$ was considered statistically significant.

\section{Results}

The ${ }^{1} \mathrm{H}-\mathrm{NMR}$ of the product, 2-benzylidene-6,7-dimethoxy-4-phenyl-3,4-dihydro-2H-naphthalen-1one, $4 \mathrm{a}$ exhibited a multiplet in the region between $\delta 3.243-3.301$ and 3.36-3.41 corresponding to $\mathrm{C}_{3}$ protons. $\mathrm{A}$ singlet was observed at $\delta 3.76$ and 3.98 corresponding to methoxy protons at $\mathrm{C}_{6}$ and $\mathrm{C}_{7}$ carbon atoms. A doublet of a doublet was observed at $\delta 4.25-4.28$ due to $\mathrm{C}_{4}$ protons. The aromatic protons were observed in the region of $\delta 6.43$ to $\delta 7.72$. A singlet in the region $\delta 7.82$ is due to the benzylideneproton. The ${ }^{1} \mathrm{H}-\mathrm{NMR}$ of the product 7,8 dimethoxy-5-phenyl-4,5-dihydro-naphtha[1,2-d] thiazol-2-yl amine (5a)) showed a multiplet in the region of $\delta$ $2.97-3.0$ and 3.16-3.22 due to $\mathrm{C}_{4}$ protons. The singlets at $\delta 3.71$ and $\delta 3.94$ are due to methoxy protons at $\mathrm{C}_{7}$ and $\mathrm{C}_{8}$. A doublet of a doublet was observed at $\delta 4.22-4.28$ due to $\mathrm{C}_{5}$ protons. A broad peak at $\delta 5.3$ is due to the corresponding to the amino group of the amino-thiazolyl ring. Aromatic protons are observed at in the region of of $\delta 6.4$ to $\delta 7.36$. The ${ }^{1} \mathrm{H},{ }^{13} \mathrm{C}$ NMR and data of all compounds are in complete agreement with assigned structure and the details are included in the experimental section.

In this study, we synthesized four novel podophyllotoxin derivatives having chalcone ring or an amino thiazolyl ring attached to the central lignin ring $(\mathbf{4 a}, \mathbf{4 b}, \mathbf{5 a}, \mathbf{5 b})$.

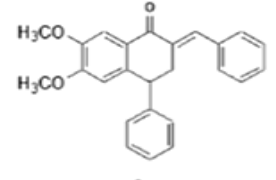

4a

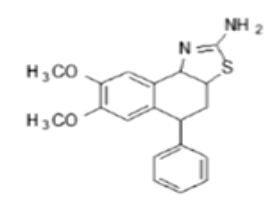

5 a
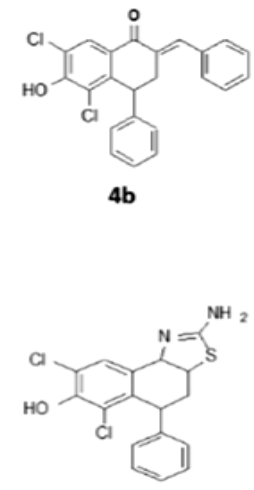

Sb

Fig 1: Structure of the compounds.

\subsection{The novel derivatives of podophyllotoxin induced time dependent cell death}

The cytotoxicity of podophyllotoxin derivatives was assessed in vitro on EAT cells by Trypan blue dye exclusion method. The number of viable cells was compared with the number of dead cells after treatment in a time dependent manner. The time kinetics of the drug showed cytotoxicity in treated cells in a time dependent manner as compared with the vehicle $(0.1 \%$ DMSO) treated control. The treatment was given at a time intervals of $45 \mathrm{~min}, 1.5 \mathrm{~h}, 3 \mathrm{~h}$ and $6 \mathrm{~h}$ wherein the maximum cytotoxicity was seen in the $6^{\text {th }}$ hour. The percentage viability of the cells treated with $\mathbf{4 a}, \mathbf{4 b}, \mathbf{5 a}, \mathbf{5 b}$ at the $6^{\text {th }}$ hour is $\mathbf{4 2 . 9 0 \%}, \mathbf{4 1 . 1 7 \%}, \mathbf{5 0 \%}$ and $\mathbf{2 0 . 5 8 \%}$ respectively as compared to the control as shown in fig 2. 

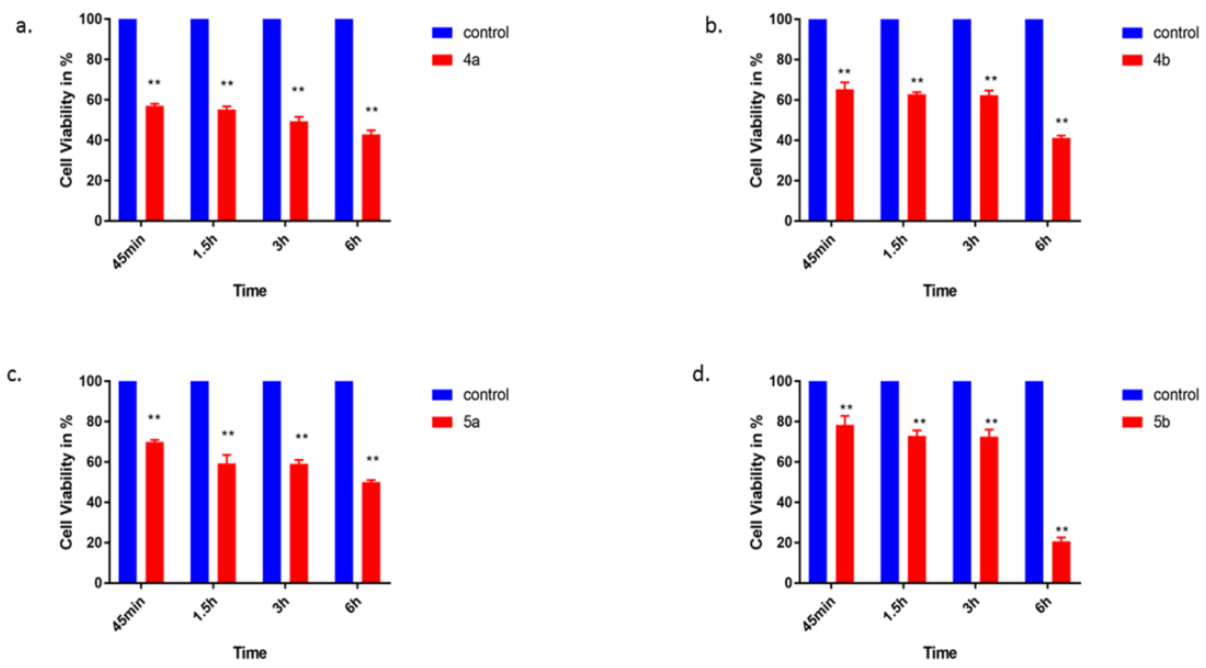

Fig 2: Cytotoxicity of EAT cells as assessed by Trypan blue dye exclusion assayin vitro: Cells $\left(5 \mathrm{x} 10^{6}\right)$ were treated with podophyllotoxin derivatives $(100 \mu \mathrm{M})$ along with control for $45 \mathrm{mins}, 1.5 \mathrm{~h}, 3 \mathrm{~h}$ and $6 \mathrm{~h}$ intervals. The cells were harvested, washed with PBS and counted after adding trypan blue dye. The viable cells were counted and thepercentage viability was calculated.Data are presented as the mean \pm SEM of three independent experiments; $* * \mathrm{P}<0.01$.

\section{Experimental Section}

All reagents were purchased from catalogue suppliers and were used without further purification. Melting and boiling points were determined using melting and boiling point apparatus (Campbell Electronics, Mumbai, India). ${ }^{1} \mathrm{H}$ NMR and ${ }^{13} \mathrm{C}$ NMR spectra were recorded on a Bruker $400 \mathrm{MHz}$ advance Ultrashield NMR spectrometer 400.23 and 100.64 respectively and referenced to $\mathrm{CDCl}_{3}$. TLC was performed on Silica gel 60 F254 (Merck) layer using hexane: ethyl acetate (3:1 v/v) as eluents.

\subsection{General procedure for the synthesis of 4-phenyl-3,4-dihydro-2H-naphthalen-1-ones, $2 \mathrm{a}$ and $2 \mathrm{~b}$ :}

To a stirred solution of 4-hydroxy-4-phenyl-butan-1-one, 1aand $\mathbf{1 b}(5 \mathrm{mmol})$ in nitromethane $(10 \mathrm{~mL})$ under nitrogen atmosphere was added p-toluene sulphonic acid monohydrate $(0.5 \mathrm{mmol})$. The reaction mixture was heated to a $70^{\circ} \mathrm{C}$ and maintained at the same temperature for 3 hours. TLC monitoring of the reaction mixture showed the absence of starting material. After the completion of the reaction, water wash $(20 \mathrm{~mL})$ was given to the reaction mixture and the organic phase was separated. The organic layer was evaporated to get the crude product. This was purified by column chromatography on silica gel using hexane/ethyl acetate as the eluent (90:10) to afford the product.

\subsubsection{6, 7-Dimethoxy-4-phenyl-3,4-dihydro-2H-naphthalen-1-one,2a}

Yellow solid, yield (78\%), m.p; $135^{\circ} \mathrm{C} .{ }^{1} \mathrm{H}-\mathrm{NMR}\left(\mathrm{CDCl}_{3}\right): \delta 2.24-2.26(\mathrm{~m}, 1 \mathrm{H}), 2.41-2.56(\mathrm{~m}, 3 \mathrm{H})$, $3.71(\mathrm{~s}, 3 \mathrm{H}), 3.84(\mathrm{~s}, 1 \mathrm{H}), 4.21-4.24(\mathrm{dd}, \mathrm{J}=5.6 \mathrm{~Hz}, 1 \mathrm{H}), 6.4(\mathrm{~s}, 1 \mathrm{H}), 7.07-7.10(\mathrm{~d}, 2 \mathrm{H}), 7.20-7.24(\mathrm{dd}, 2 \mathrm{H})$, 7.24-7.31 (dd, 2H), $7.57(\mathrm{~s}, 1 \mathrm{H}) .{ }^{13} \mathrm{C}-\mathrm{NMR}\left(\mathrm{CDCl}_{3}\right): \delta 32.61,36.16,45.34,56.37,56.45,108.71,111.45$, $111.71,126.71,126.72,127.23,128.95,129.04,141.31,144.06,148.64,154,197.52$;

\subsubsection{5, 7-Dichloro-6-hydroxy-4-phenyl-3,4-dihydro-2H-naphthalen-1-one, 2b}

Yellow solid, yield $(61 \%)$. m.p. $146^{\circ} \mathrm{C} .{ }^{1} \mathrm{H}-\mathrm{NMR}\left(\mathrm{CDCl}_{3}\right): \delta 2.17-2.23(\mathrm{~m}, 1 \mathrm{H}), 2.39-2.47(\mathrm{~m}, 1 \mathrm{H})$, 2.58-2.76 (m, 2H), 4.18-4.21 (dd, J = 4.4 Hz, 1H), 6.96-6.98 (d, 1H), 7.0 (s, 1H), 7.36-7.39 (t, 1H), 7.45-7.49 $(\mathrm{m}, 1 \mathrm{H}), 8.10-8.12(\mathrm{dd}, 1 \mathrm{H}) .{ }^{13} \mathrm{C}-\mathrm{NMR}\left(\mathrm{CDCl}_{3}\right): \delta 32.16,36.99,121.86,127.88,127.99,128.71,129.77,133.04$, $134.42,137.51,145.48,147.32,198$;

5.2. General procedure for the synthesis of 2-bromo-4-phenyl-3,4-dihydro-2H-naphthalen-1-ones, 3a and 3b:A solution of 4-phenyl-3,4-dihydro-2H-naphthalen-1-one, $(4 \mathrm{mmol})$ in acetonitrile $(50 \mathrm{~mL})$ was mixed with p-toluene sulphonic acid $(6 \mathrm{mmol})$ and heated to $65^{\circ} \mathrm{C}$. At $65^{\circ} \mathrm{C}, \mathrm{N}$-bromosuccinimide $(4 \mathrm{mmol})$ was slowly added in lots over a period of 1 hour. The reaction mixture was stirred for $4-5 \mathrm{~h}$ at the same temperature. The reaction mixture after completion was diluted with ethyl acetate $(100 \mathrm{~mL})$ and washed with water $(2 \mathrm{x} 50 \mathrm{~mL})$. The ethyl acetate layer was separated and ethyl acetate evaporated to give crude product. The crude product was recrystallized from ethanol to give a light brown solid, $(0.98 \mathrm{~g}, 68 \%)$. 
5.2.1.2-bromo-6,7-dimethoxy-4-phenyl-3,4-dihydro-2H-naphthalen-1-one, (3a):

Light brown solid, yield (68\%),m.p. $160^{\circ} \mathrm{C} .{ }^{1} \mathrm{H}-\mathrm{NMR}\left(\mathrm{CDCl}_{3}\right): \delta 2.66-2.67(\mathrm{~m}, 2 \mathrm{H}), 3.68(\mathrm{~s}, 1 \mathrm{H}), 3.93(\mathrm{~s}, 1 \mathrm{H})$ $4.45-4.49(\mathrm{dd}, 1 \mathrm{H}), 4.73-4.75(\mathrm{dd}, 1 \mathrm{H}), 6.30(\mathrm{~s}, 1 \mathrm{H}), 7.18-7.20(\mathrm{dd}, 2 \mathrm{H}), 7.30-7.38(\mathrm{~m}, 3 \mathrm{H}), 7.59(\mathrm{~s}, 1 \mathrm{H}) .{ }^{13} \mathrm{C}-$ NMR $\left(\mathrm{CDCl}_{3}\right): \delta 41.7,42.9,49.6,56.4,56.5,109.7,111.17,111.38,123.72,127.24,127.80,127.96,128.97$, $129.08,129.58,141.20,148.95,154.71,189.93$.

5.2.2. 2-bromo-5,7-dichloro-6-hydroxy-4-phenyl-3,4-dihydro-2H-naphthalen-1-one, (3b):

Light brown solid, yield $(65 \%)$, m.p. $171^{\circ} \mathrm{C} .{ }^{1} \mathrm{H}-\mathrm{NMR}\left(\mathrm{CDCl}_{3}\right): \delta 2.60-2.63(\mathrm{~m}, 2 \mathrm{H}), 4.45-4.48(\mathrm{dd}, 1 \mathrm{H}), 4.75-$ $4.77(\mathrm{dd}, 1 \mathrm{H}), 7.109$ (s, 3H), 7.38-7.47 (dd, 1H), 7.51-7.52 (dd, 1H), 8.14-8.16 (dd,1H).

\subsection{General procedure for the synthesis of chalcone derivatives $4 \mathrm{a}, \mathbf{4 b}$}

Benzaldehyde (0.0025 moles) was stirred with a solution of 4-phenyl-3,4-dihydro-2H-naphthalen-1one $(0.0025$ moles $)$ in ethanol at room temperature. $\mathrm{NaOH}(0.50$ moles $)$ was added and the reaction mixture stirred at the same temperature for 10 hours. After completion, the reaction mixture was acidified with $20 \% \mathrm{HCl}$ to $\mathrm{pH}=4$ and then extracted with ethyl acetate $(50 \mathrm{~mL})$. The ethyl acetate layer was evaporated to give a solid which was purified by column chromatography on silica gel using hexane/ethyl acetate (80: 20) as the eluent to give the product.

\subsubsection{2-benzylidene-6,7-dimethoxy-4-phenyl-3,4-dihydro-2H-naphthalen-1-one (4a)}

pale yellow solid, yield $(72 \%)$. m.p.: $172{ }^{\circ} \mathrm{C} .{ }^{1} \mathrm{H}-\mathrm{NMR}\left(\mathrm{CDCl}_{3}\right): \delta 3.243-3.301(\mathrm{~m}, 1 \mathrm{H}), 3.36-3.41(\mathrm{~m}, 1 \mathrm{H})$, $3.76(\mathrm{~s}, 3 \mathrm{H}), 3.98(\mathrm{~s}, 3 \mathrm{H}), 4.25-4.28(\mathrm{dd}, 1 \mathrm{H}), 6.43(\mathrm{~s}, 1 \mathrm{H}), 7.11-7.13(\mathrm{~d}, 2 \mathrm{H}), 7.16-7.18(\mathrm{~d}, 2 \mathrm{H}), 7.233$-7.32 (m, $6 \mathrm{H}), 7.72(\mathrm{~s}, 1 \mathrm{H}), 7.83(\mathrm{~s}, 1 \mathrm{H}) .{ }^{13} \mathrm{C}-\mathrm{NMR}\left(\mathrm{CDCl}_{3}\right): \delta 36.16,45.28,56.41,56.58,109.9,110.93,127.38,128.68$, $128.76,129.09,129.89,134.07,136.22,137.49,140.73,143.72,148.95,154.14,187.25$.

5.3.2.2-benzylidene-5,7-dichloro-6-hydroxy-4-phenyl-3,4-dihydro-2H-naphthalen-1-one (4b)

Cream coloured solid. Yield (70\%), m.p.182 ${ }^{\circ} \mathrm{C} .{ }^{1} \mathrm{H}-\mathrm{NMR}\left(\mathrm{CDCl}_{3}\right): \delta 3.26-3.28(\mathrm{~m}, 1 \mathrm{H}), 3.37-3.41(\mathrm{~m}, 1 \mathrm{H})$, 4.17-4.22 (dd, 1H), 6.98-7.0 (S, 3H), 7.26-7.49 (m, 7H), 7.88-7.91 (s, 1H), 8.21-8.24 (d, 1H); ${ }^{13} \mathrm{C}-\mathrm{NMR}\left(\mathrm{CDCl}_{3}\right)$ : $\delta 35.5744 .20121 .7,128.3,128.4,128.88,128.97,129.03,130.07,133,7,134.2,135.80,136.87,138.81$, $144.57,147.21,187.82$.

\subsection{General procedure for the synthesis of amino-thiazolyl derivatives $5 \mathrm{a}, \mathbf{5 b}$}

Thiourea (0.0015 moles) was added to stirred solution of 2-bromo--4-phenyl-3,4-dihydro-2H-naphthalen-1-ones 3a, 3b $(0.0015$ moles $)$ in DMF $(10 \mathrm{~mL})$ at room temperature. The reaction mixture was stirred at the same temperature for $10 \mathrm{~h}$. After completion, the reaction mixture was poured into water $(150 \mathrm{~mL})$ and extracted with ethyl acetate $(50 \mathrm{~mL})$. The organic layer after separation was stripped to get a solid which was recrystallized from $10 \%$ ethanol to afford the product.

\subsubsection{7,8-dimethoxy-5-phenyl-4,5-dihydro-naphtha[1,2-d] thiazol-2-yl amine (5a)}

Cream coloured solid, yield $(80 \%)$, m.p. $106{ }^{\circ} \mathrm{C} .{ }^{1} \mathrm{H}-\mathrm{NMR}\left(\mathrm{CDCl}_{3}\right): \delta 2.97-3.03(\mathrm{~m}, 1 \mathrm{H}), 3.16-3.22(\mathrm{~m}, 1 \mathrm{H})$, $3.71(\mathrm{~s}, 3 \mathrm{H}), 3.94(\mathrm{~s}, 3 \mathrm{H}), 4.22-4.28(\mathrm{dd}, 1 \mathrm{H}), 5.3(\mathrm{br}, 2 \mathrm{H}), 6.4(\mathrm{~s}, 1 \mathrm{H}), 7.16-7.36(\mathrm{~m}, 6 \mathrm{H}) .{ }^{13} \mathrm{C}-\mathrm{NMR}\left(\mathrm{CDCl}_{3}\right): \delta$ $31.01,45.4$, 45.34, 56.36, 56.57, 106.98, 112.6, 116.3, 124.7, 127.3, 128.7, 129.02, 129.71, 144.44, 144.72, $148.38,148.48,166.73$.

\subsubsection{2-amino-6,8-dichloro-5-phenyl-4,5-dihydro-naphtho[1,2-d] thiazol-7-ol (5b)}

Off-white coloured solid, yield $(82 \%)$, m.p. $120^{\circ} \mathrm{C} .{ }^{1} \mathrm{H}-\mathrm{NMR}\left(\mathrm{CDCl}_{3}\right): \delta 2.97-3.01(\mathrm{~m}, 1 \mathrm{H}), 3.17-3.21(\mathrm{~m}, 1 \mathrm{H})$, 4.22-4.24 (dd, 1H), $5.3(\mathrm{br}, 2 \mathrm{H}), 6.88-6.90(\mathrm{dd}, 1 \mathrm{H}), 7.07(\mathrm{~s}, 2 \mathrm{H}), 7.127-7.246(\mathrm{~m}, 1 \mathrm{H}), 7.167-7.313(\mathrm{~m}, 1 \mathrm{H})$, 7.76-7.78 ( dd, $1 \mathrm{H}) .{ }^{13} \mathrm{C}-\mathrm{NMR}\left(\mathrm{CDCl}_{3}\right): \delta 31.01,45.4,45.34,56.36,56.57,106.98,112.6,116.3,124.7,127.3$, $128.7,129.02,129.71,144.44,144.72,148.38,148.48,166.73$.

\section{Discussion and Conclusion}

In the current study we have synthesized chalcone and aminothiazole derivatives of podophyllotoxin and evaluated their potential as cytotoxic agents on murine mammary carcinoma cells. Thefour derivatives of podophyllotoxin namely the chalcone derivatives, 2-benzylidene-6, 7-dimethoxy-4-phenyl-3, 4-dihydro-2Hnaphthalen-1-one (4a) and 2-benzylidene-5, 7-dichloro-6-hydroxy-4-phenyl-3, 4-dihydro-2H-naphthalen-1-one (4b) and aminothiazolyl derivatives, 7,8-dimethoxy-5-phenyl-4,5-dihydro-naphtha[1,2-d] thiazol-2-yl amine (5a) and 2-amino-6,8-dichloro-5-phenyl-4,5-dihydro-naphtho[1,2-d] thiazol-7-ol (5b) were synthesized and compared for their ability to induce cytotoxicity. Recent reports on podophyllotoxin derivatives suggest that they can be potential anti-tumor drugs by the induction of apoptosis and inhibiting tumor angiogenesis [20][18]. The in vitro cell based cytotoxicity assay is a useful and reliable method to demonstrate the activity of chemotherapeutic drugs and also gives a prior knowledge of the efficacy of various agents before using in invivo 
and clinical trials [21].The Ehrlich Ascites tumor is a murine mammary adenocarcinoma which grows in mice by intra peritoneal passages. The ascitic form of the tumor is the chosen experimental model to evaluate the influence of various drugs on its proliferation and host interaction against the cancer cells [22].Hence we used the Ehrlich Ascites Tumor cells for in vitroexperiments. In order to assess the toxicity of the compounds and evaluate their base-line metabolic effects on the cell [23], the trypan blue dye exclusion method of testing the cytotoxicity of these novel drugs in vitroon murine mammary carcinoma (EAT) cells was done.

The data presented in this paper reflects mainly on the in vitro ability of6,7-dimethoxy-4-phenyl substituted compounds(4a,5a)and5,7-dichloro-6-hydroxy-4-phenyl substituted compounds $(\mathbf{4 b}, \mathbf{5 b})$ to inhibit both growth and proliferation of mouse mammary carcinoma cells.Our in vitro experiments suggested that both 5,7-dichloro-6-hydroxy-4-phenyl substituted compounds (4b,5b) and 6,7-dimethoxy-4-phenyl substituted compounds $(\mathbf{4 a}, \mathbf{5 a})$ showed superior cytotoxicity in EAT cells in a time dependent manner.

In conclusion, we have synthesized four novel derivatives of podophyllotoxin namely 2-benzylidene6,7-dimethoxy-4-phenyl-3,4-dihydro-2H-naphthalen-1-one(4a),2-benzylidene-5,7-dichloro-6-hydroxy-4-

phenyl-3,4-dihydro-2H-naphthalen-1-one(4b),7,8-dimethoxy-5-phenyl-4,5-dihydro-naphtha[1,2-d] thiazol-2-yl amine (5a)and2-amino-6,8-dichloro-5-phenyl-4,5-dihydro-naphtho[1,2-d] thiazol-7-ol (5b) in moderate to good yields. They were further characterized by ${ }^{1} \mathrm{H},{ }^{13} \mathrm{C}$ NMR. Our preliminary assessment shows that theyare promising cytotoxic candidates that can be further explored for anti-tumor assessment. Further confirmatory studies on different cell based and in-vivo models are essential to understand their potential as anti-tumor agents in different cancers.

\section{Acknowledgements}

We acknowledge funding of JRF fellowship from DST-INSPIRE (Department of Science and Technology-Innovation in Science Pursuit for Inspired Research), Govt. of India.,[S.C.P., No.DST/INSPIRE Fellowship/2012 dated $28^{\text {th }}$ May, 2012].

\section{References}

[1]. J.C. Kathryn, G. Sireesha V, L. Stanley, Triple Negative Breast Cancer Cell Lines: One Tool in the Search for Better Treatment of Triple Negative Breast Cancer, Breast Dis. 32, 2012, 35-48. doi:10.3233/BD-2010-0307.

[2]. S Koch, F Mayer, F Honecker, M Schittenhelm and C Bokemeyer, Efficacy of cytotoxic agents used in the treatment of testicular germ cell tumours under normoxic and hypoxic conditions in vitro. Br. J. Cancer, 89, 2003, 2133-2139.

[3]. S.Y. Yoo, S.M. Kwon, Angiogenesis and its therapeutic opportunities, Mediators Inflamm. 2013 . doi:10.1155/2013/127170.

[4]. M.J. Higgins, J. Baselga, Review series Targeted therapies for breast cancer, J. Clin. Invest. 121, $2011,3797-3803$. doi:10.1172/JCI57152.

[5]. A Kumar, S D'Souza, SL Gaonkar, KML Rai, BP Salimath, Growth inhibition and induction of apoptosis in MCF-7 breast cancer cells by a new series of substituted-1,3,4-oxadiazole derivatives. Invest New Drugs 26, 2008, 425-435. doi 10.1007/s10637-0089116-5.

[6]. C Anil Kumar, S Jayarama, Basappa, BP Salimath, KS Rangappa, Pro-apoptotic activity of imidazole derivatives mediated by upregulation of Bax and activation of CAD in Ehrlich Ascites Tumor cells. Invest New Drugs 25, 2007, 343-350. doi 10.1007/s10637-006-9033-4

[7]. E.E.Smissman, R.J. Murrey, J.D. McChesney, L.L. Houston, T.L. Pazdernik, Podophyllotoxin analogs, Synthesis and biological evaluation of certain trans-2-aryl-trans-6-hydroxymethyl-3-cyclohexenecarboxylic acid gamma.-lactones as antimitotic agents, J. Med. Chem.19, 1976, 148-153.

[8]. M. Abdelrahim, S. Konduri, Md. R. Basha, P.A. Philip and C. H. Baker, Angiogenesis: An update and potential drug approaches (Review), International Journal of Oncology 36: 2010, 5-18. doi: 10.3892/ijo_00000470.

[9]. Y. Qian Liu, L. Yang, X. Tian, Podophyllotoxin: Current Perspectives, Curr Bioact Compd., 2007. doi:10.2174/157340707780126499.

[10]. A. Stoll, J. Renz, A.V. Wartburg, The isolation of podophyllotoxin glucoside, J. Am. Chem. Soc. (76), 1954, 3103-3104.

[11]. M. Kuhn, A.von Wartburg, ÜbereinneuesGlykosidierungsverfahren II. Glykoside des 4'-Demethylepipodophyllotoxins. 23. MitteilungübermitosehemmendeNaturstoffe [1] Helv. Chim. Acta, 52, 1969, 948-955.

[12]. S. Joel, The clinical pharmacology of etoposide: an update, Cancer Treat. Rev. 22, 1996, 179-221.

[13]. R.N. Misra, H.Y. Xiao, K.S. Kim, S. Lu, W.C. Han, S.A. Barbosa, J.T. Hunt, D.B. Rawlins, W. Shan, S. Z. Ahmed, L. Qian, B.C. Chen, R. Zhao, M.S. Bednarz, K.A. Kellar, J.G. Mulheron, R. Batorsky, U. Roongta, A. Kamath, P. Marathe, S.A. Ranadive, J.S. Sack, J.S. Tokarski, N.P. Pavletich, F.Y. Lee, K.R. Webster, S.D. Kimball, N-(cycloalkylamino)acyl-2-aminothiazole inhibitors of cyclin-dependent kinase 2. N-[5-[[[5-(1,1-dimethylethyl)-2-oxazolyl]methyl]thio]-2-thiazolyl]-4-piperidinecarboxamide (BMS387032), a highly efficacious and selective antitumour agent, J. Med. Chem. 47,2004, 1719-1728.

[14]. Z. Nowakowska A review of anti-infective and anti-inflammatory chalcones, Eur. J. Med. Chem. 42,2007, $125-137$.

[15]. P.M. Sivakumar, S. Ganesan, P. Veluchamy, M. Doble, Novel chalcones and 1,3,5-triphenyl-2-pyrazoline derivatives as antibacterial agents, Chem. Biol. Drug. Des. 76,2010, 407-411. doi: 10.1111/j.1747-0285.2010.01020.

[16]. D. Kumar, N.M. Kumar, K. Akamatsu, E. Kusaka, H. Harada, T. Ito, Synthesis and biological evaluation of indolylchalcones as antitumor agents, Bioorg. Med. Chem. Lett. 20,2011, 3916-3919. doi: 10.1016/j.bmcl.2010.05.016. Epub 2010 May 13.

[17]. R. Nishimura, K. Tabata, M. Arakawa, Y.Ito, Y. Kimura, T. Akihisa, H. Nagai,A. Sakuma, H. Kohno, T. Suzuki, Isobavachalcone, a Chalcone Constituent of Angelica keiskei, Induces Apoptosis in Neuroblastoma , Biol. Pharm. Bull. 30.2007,1878-1883.

[18]. A. Kamal, J.R. Tamboli, M.J. Ramaiah, S.F. Adil, S.N.C.V.L. Pushpavalli, R. Ganesh, P. Sarma, U. Bhadra, M. Pal-Bhadra, Quinazolino linked 4 $\beta$-amidopodophyllotoxin conjugates regulate angiogenic pathway and control breast cancer cell proliferation, Bioorganic Med. Chem. 21, 2013, 6414-6426. doi:10.1016/j.bmc.2013.08.051.

[19]. P. Sunil Kumar and K.M.L. Rai, Cleavage of 3-Aryl-5,6-dihydro-4H-1,2-oxazines Using Zinc and Aqueous Chelating Ethers: Efficient Methodology for N-O Bond Cleavage. Letters in Organic Chemistry 9(6), 2012, 440-446. doi: 
$10.2174 / 157017812801322471$.

[20]. Z. Jiang, M. Wu, J. Miao, H. Duan, S. Zhang, M. Chen, L. Sun, Y. Wang, X. Zhang, X. Zhu, L. Zhang, Deoxypodophyllotoxin exerts both anti-angiogenic and vascular disrupting effects, Int. J. Biochem. Cell Biol. 45, 2013 , $1710-1719$. doi:10.1016/j.biocel.2013.04.030.

[21]. F. Leila, M. Ronald, T. Elena, S. Katherine, C. Frederick, T. Alexander, Comparison of Cytotoxic Activity of Anticancer Drugs against Various Human Tumor Cell Lines Using In Vitro Cell-Based Approach, Int J Biomed Sci, Vol. 8 No.1, 2012. www.ijbs.org

[22]. C. Calixto-Campos, A.C. Zarpelon, M. Corrêa, R.D.R. Cardoso, F.A. Pinho-Ribeiro, R. Cecchini, E.G. Moreira, J. Crespigio, C.C.F. Bernardy, R. Casagrande, W.A. Verri, The ehrlich tumor induces pain-like behavior in mice: A novel model of cancer pain for pathophysiological studies and pharmacological screening, Biomed Res. Int., 2013, doi:10.1155/2013/624815.

[23]. S. Altman, L. Randers, G. Rao, Comparison of trypan blue dye exclusion and fluorometric assays for mammalian cell viability determinations., Biotechnol. Prog. 9 (1999) 671-674. doi:10.1021/bp00024a017. 